\title{
POLITICAL DYSFUNCTION AND THE ELECTION OF DONALD TRUMP: PROBLEMS OF THE U.S. CONSTITUTION'S PRESIDENCY
}

\author{
DAVID ORENTLICHER ${ }^{*}$
}

\section{INTRODUCTION}

This Article discusses a critical, but overlooked, cause of political dysfunction in the United States-the Constitution's design for the executive branch. Specifically, this Article argues that by opting for a single executive rather than a multi-person executive, the Constitution causes two serious problems - it fuels the high levels of partisan polarization that we see today, and it increases the likelihood of misguided presidential decision making.

Drawing on the experience in other countries with executive power shared by multiple officials, this Article proposes a bipartisan executive. By adopting a twoperson, two-party presidency, we would do much to promote a more effective political system. Giving meaningful representation to persons across the political spectrum would defuse partisan conflict and ensure that public policy reflects a broad range of policy perspectives.

A bipartisan executive would especially do much to address concerns about the election of Donald Trump in November 2016. His erratic temperament and use of fascist rhetoric ${ }^{1}$ have highlighted the risk that an authoritarian executive could misuse the enormous power of the Oval Office. A presidential partner would provide an important check on autocratic behavior, especially when the President's party controls Congress and therefore is not likely to push back against executive decision making.

I began my thinking about political dysfunction while immersed in partisan conflict as a Democratic state representative in Indiana. ${ }^{2}$ Like most candidates for office, I had promised to work with colleagues on both sides of the aisle. I pledged to judge ideas by whether they were good or bad, not whether they were

* Samuel R. Rosen Professor, Indiana University Robert H. McKinney School of Law. MD, JD, Harvard University. Much of the material in this article is drawn from David Orentlicher, Two Presidents Are Better Than One: The Case for a Bipartisan Executive Branch (2013), and most elements of this article were initially presented at the Indiana Law Review's 2015 annual symposium, Partisan Conflict, Political Structure, and Culture, held at Indiana University Robert H. McKinney School of Law on November 6, 2015. I am grateful for the editorial assistance of Kristina Frey, Scott Frissell, Ashley Hart, Tyler Haston, Michael Heavilon, Matthew Koressel, and R. Alexander Swider.

1. Matthew Filner, American Fascism: The Presidency of Donald J. Trump, PuB. SEMINAR (Nov. 10, 2016), http://www.publicseminar.org/2016/11/american-fascism/\#.WDBgPPkrLIU [https://perma.cc/9MCU-LX3J].

2. I served three terms, from 2002 to 2008 until I gave up my seat to run for Congress, in an unsuccessful campaign. See Arena Profile: David Orentlicher, Politico: ArenA, http://www. politico.com/arena/bio/david_orentlicher.html [https://perma.cc/66XG-9NE5] (last visited Nov. 6, 2016).

http://doi.org/10.18060/4806.1137 
proposed by Democrats or Republicans.

And while I tried very hard to do that - and I think I did a better job than most at working across the aisle-I found out quickly that it was very difficult to remain above the partisan fray. Try as one might to choose the path of bipartisanship, one would get sucked into the partisan wrangling. It became clear to me that there must be some feature of our political system that promotes the high levels of partisan behavior that plague American politics. In other words, our partisan conflict is not so much a matter of who we elect as it is a matter of the system into which we elect them.

To be sure, partisan conflict is not all bad. We want elected officials to bring different perspectives to the nation's problems and debate how we should solve those problems. No person or party has all of the answers. We need to recognize the truths of conservatism and liberalism, and we also need to recognize the defects of conservatism and liberalism. It is good to have some degree of partisan conflict; the country benefits from a healthy level of partisan competition.

But we also want elected officials from different parties to complement conflict with compromise. At some point, presidents and members of Congress need to work together so they can reconcile their differences in a way that moves the country forward. There is a lot of common ground among Americans from different parties, and elected officials could accomplish much on that common ground.

Under our current system, the balance between conflict and cooperation is skewed too much toward conflict. The incentives to emphasize the areas of disagreement are too strong, and the incentives to focus on the areas of agreement too weak. As a result, our system of government encourages unhealthy levels of political polarization in Washington, D.C. and state capitals. We see too much obstruction for obstruction's sake rather than legitimate obstruction on grounds of principle.

In thinking about the features of our political system that fuel partisan conflict in Washington, I came to the view that I wrote about in my book, Two Presidents Are Better Than One, ${ }^{3}$ and that I have been developing further since publication of the book - an important aspect of partisan conflict is the fact that we give all of the executive power to one President rather than have the executive power shared by multiple officeholders.

Of course, this was something the founding fathers thought about and debated. ${ }^{4}$ Should we have a single executive or a multi-person executive branch ${ }^{5}$ There were good reasons in 1787 for the delegates to the Constitutional Convention to settle on a single executive. ${ }^{6}$ But as our country has changed over

3. ORENTLICHER, supra note *.

4. See 3 The Founders' Constitution 491-94 (Philip B. Kurland \& Ralph Lerner eds., 1987); James Madison, The Debates in the Federal Convention of 1787 Which Framed the Constitution of THE United States of America 48-51, 101-04 (Gaillard Hunt \& James Brown Scott eds., 1987).

5. Id.

6. MADISON, supra note 4. 
time, the executive branch has changed too, and it has changed in two ways that have been problematic.

First, the founding fathers expected presidents to view the entire country as their constituency. ${ }^{7}$ Unlike members of the House who represent a single congressional district, or members of the Senate who represent a single state, presidents represent everyone. ${ }^{8}$ Accordingly, the framers thought chief executives would follow the example of George Washington, who said about his presidency that he had "sought the happiness of [his] fellow citizens" by overlooking "all personal, local, and partial considerations" and by contemplating "the United States as one great whole." But modern presidents do not really see themselves as representing everyone. Rather, they have become standard-bearers for their parties and their party platforms. ${ }^{10}$

At the same time, the presidency has changed in another important way. The modern White House has assumed a far greater amount of policymaking power than envisioned for an "executive" branch that was designed to carry out policies passed by Congress. ${ }^{11}$ Indeed, the Oval Office has become the most important policymaking center in the national government.

So we now have a President who exercises much greater power than anticipated, but on behalf of only fifty percent of the public. Only one side of the political aisle has a meaningful voice in presidential policymaking. As a result, nearly half the public is disempowered and is prone to disaffection and resistance. The party out of power can exploit this disaffection by opposing presidential proposals, contributing to the highly partisan voting that typifies Congress today.

If having a very powerful President who represents just one party fuels partisan conflict, that suggests we would do better with an executive branch where power is shared across party lines, as is common in other democracies-hence, my proposal for a bipartisan executive.

In short, I hope to persuade readers of two points:

1. The seeds for political dysfunction were planted when the founding fathers chose a single President to head the executive branch. ${ }^{12}$

2. The best way to address political dysfunction is to change to a two-person, two-party presidency, in which the two presidents are true equals and come from different political parties. ${ }^{13}$ In a bipartisan White House, the presidential partners would have to agree whether to sign legislation, whether to issue an executive order, or whom to appoint to a cabinet position or judicial seat. ${ }^{14}$

7. $I d$.

8. Id.

9. B. Dan Wood, The Myth of Presidential Representation 6 (2009).

10. See infra Part I.

11. See id.

12. See infra Parts I-III.

13. See infra Part IV.

14. See infra Part IV.B. 


\section{The Development of Presidential Policymaking Power}

I do not mean to be too critical of the constitutional drafters. Under the framers' vision of the presidency, it made good sense to adopt a single executive. National policy was to be determined through a deliberative process involving a diverse body of legislators in the House and Senate, with the President responsible for implementing-executing-the legislature's policies. ${ }^{15}$ In that kind of a system, the Federalist Papers' energetic executive, who could act decisively and with dispatch, ${ }^{16}$ would fit well.

But a single executive does not fit so well with the modern presidency. The twenty-first century executive is not simply an executor of policy determined by Congress. Rather, the modern President exercises a substantial amount of policymaking power. Presidents oversee a sprawling federal bureaucracy of agencies that issue rules for a wide range of matters-air quality, energy exploration, education, health care, consumer protection, and many other concerns. ${ }^{17}$ And they do so under vague legislative instructions, such as to issue regulations that are "requisite to protect the public welfare." 18

Presidents also have other policy-making tools at their disposal. They can establish national policy through signing statements, executive orders, and the

15. It is Congress that debates legislative proposals and votes on whether to pass them. The President can only decide between signing and vetoing a bill. U.S. CONST. art. I, § 7. Alexander Hamilton's discussion of executive power in the Federalist Papers echoes the constitutional text. With regard to making domestic policy, the President could merely "recommend to the consideration of Congress such measures as he shall judge necessary and expedient." THE FEDERAList No. 69, at 339 (Alexander Hamilton) (Lawrence Goldman ed., 2008) (discussing Article II, Section 3 of the U.S. Constitution). More specifically, with regard to the power to regulate interstate commerce, a critically important power of the federal government, the President could "prescribe no rules concerning the commerce ... of the nation." Id. at 343. The Constitution grants presidents the authority to make treaties with foreign countries, but even then, Senate approval is necessary. U.S. ConST. art. II, $\S 2, \mathrm{cl}$. 2. To be sure, some scholars argue that when the Constitution vests the "executive power" in "a President," Art. II, $\S 1$, cl. 1, the framers understood the executive power to include individual powers beyond merely executing the will of Congress. Saikrishna B. Prakash \& Michael D. Ramsey, The Executive Power over Foreign Affairs, 111 YALE L.J. 231, 252-54 (2001). However, rather than reading the Constitution's vesting of executive power as a vehicle for granting broad power to the executive branch, the better reading of the purpose of the Vesting Clause is to declare that the power to execute the law rests with the President rather than with other government officials. Lawrence Lessig \& Cass R. Sunstein, The President and the Administration, 94 Colum. L. REv. 1, 47-48 n.195 (1994). Any powers beyond that of executing the law are spelled out in Article I, Section 2 (e.g., the power to command the military).

16. The Federalist No. 70 (Alexander Hamilton) (Lawrence Goldman ed., 2008).

17. The Executive Branch, White House, https://www.whitehouse.gov/1600/executivebranch [https://perma.cc/V67X-FRFK] (last visited Nov. 7, 2016).

18. 42 U.S.C. $\S 7409$ (b)(2) (2012). 
granting of waivers from statutory obligations. ${ }^{19}$

Consider just a few examples from the Obama administration. By 2025, rules issued by the Environmental Protection Agency (EPA) and the Department of Transportation will have doubled fuel efficiency requirements for cars and light trucks from the time that President Obama took office. ${ }^{20}$ Obama also expanded offshore drilling for oil and gas, ${ }^{21}$ granted expansive waivers to states from the No Child Left Behind law, ${ }^{22}$ and reversed the limits on federal funding for stem cell research that had been imposed by George W. Bush. ${ }^{23}$

While presidents exercise considerable domestic authority, they dominate Congress even more in foreign affairs. Presidents play a far larger role in the determination of U.S. policy - and Congress plays a far smaller role-than intended by the framers. ${ }^{24}$ From Truman in Korea to Obama in Libya, presidents have sent troops into combat without congressional authorization. ${ }^{25}$ Presidents also reach agreements with other countries without congressional participation, ${ }^{26}$

19. See Eric Posner \& Curtis A. Bradley, Presidential Signing Statements and Executive Power 1-7 (U. Chi. Pub. Law \& Legal Theory, Working Paper No. 133, 2006).

20. Bill Vlasic \& John Broder, U.S. Sets High Long-Term Fuel Efficiency Rules for Automakers, N.Y. Times, Aug. 29, 2012, at B1.

21. John M. Broder, Re-Election Strategy Is Tied to a Shift in Smog, N.Y. TIMES, Nov. 17, 2011, at A1.

22. Motoko Rich, 'No Child' Law Whittled Down by White House, N.Y. Times, July 6, 2012, at $\mathrm{A} 1$.

23. Gardiner Harris, Rules Will Allow Financing for Old Stem Cell Lines, N.Y. TimEs, July 6,2009 , at D2.

24. When the Constitution assigns powers relating to foreign policy, it mostly assigns them to Congress. Thus, under Article I, Congress has the power to regulate commerce with other countries, to determine when foreign citizens can become U.S. citizens, to make violations of international law violations of federal law, to declare war, and to raise and support military forces. U.S. ConsT. art. I, $\S 8$. Presidential powers under Article II are much more limited and mostly shared with the Senate. U.S. CONST. art. II. The President is commander in chief of the military forces, makes treaties with Senate advice and consent, and appoints ambassadors with Senate advice and consent. Id. $\S 2$, cl. 1-2. (The President also receives ambassadors from other countries, but that authority falls under Section 3 of Article II, which lists presidential duties rather than powers.). See id. $\S 3$.

25. Other examples include Bill Clinton with military assaults in Kosovo and Sudan. See John C. Yoo, Kosovo, War Powers, and the Multilateral Future, 148 U. PA. L. ReV. 1673, 1675, 1679 (2000).

26. The great majority of agreements with foreign countries today take the form of "ex ante congressional-executive agreements," in which Congress grants the President broad authority to fashion agreements with foreign countries on military cooperation, drug interdiction, economic trade, or other policy matters. See generally Oona A. Hathaway, Presidential Power over International Law: Restoring the Balance, 119 YALE L.J. 140 (2009). The broad discretion granted to presidents for these agreements is similar to the broad discretion granted to the executive branch for rulemaking on matters of domestic policy. $I d$. 
they unilaterally recognize other governments and terminate treaties, ${ }^{27}$ and they decide on their own about restrictions on the rights of U.S. citizens to travel abroad. ${ }^{28}$ Presidents also revise our immigration policy. When Congress did not create a path to citizenship for young undocumented immigrants, President Obama implemented his own DREAM Act by waiving deportation of 800,000 young immigrants and granting them work permits. ${ }^{29}$ And when Congress did not pass broad immigration reform, President Obama offered deferred action to another five million immigrants. ${ }^{30}$

Whether the executive branch has amassed too much power is an important question. There are important reasons for the transfer of power from the legislative branch to the executive branch, but there also are important concerns about the transfer. On one hand, as the Supreme Court has observed, "in our increasingly complex society, replete with ever changing and more technical problems, Congress simply cannot do its job absent an ability to delegate power under broad general directives." ${ }^{31}$ On the other hand, we should worry that Congress may yield its authority in order to escape responsibility for controversial decisions. ${ }^{32}$ The public may applaud when Congress passes a law to clean up the environment, but people may become less enthusiastic when the EPA issues rules that exact a price for environmental protection.

But even if the executive branch does not have too much power, it has too much power for one person. No single official should exercise all of the power of the American presidency.

\section{The Single Executive And Partisan Conflict}

When one person exercises the substantial policy-making power of the modern U.S. presidency, we drive people more toward conflict and away from cooperation. A single President represents the views of just one political party. Despite the common perception that presidents move to the middle to appeal to

27. President Jimmy Carter decided that we would recognize mainland China instead of Taiwan as the legitimate government of China. Goldwater v. Carter, 617 F.2d 697, 700 (D.C. Cir.), vacated, 444 U.S. 996 (1979).

28. President Dwight Eisenhower decided that Americans could not travel to Cuba, later presidents maintained the policy, and President Barack Obama decided to ease travel restrictions when he reestablished relations with Cuba. Peter Baker, U.S. Will Restore Full Relations with Cuba, Erasing a Last Trace of Cold War Hostility, N.Y. TimES, Dec. 8, 2014, at A1.

29. Julia Preston \& John H. Cushman, Jr., Obama to Permit Young Migrants to Remain in U.S., N.Y. TIMES, June 16, 2012, at A1.

30. Adam Liptak \& Michael D. Shear, Justices to Hear State Challenge on Immigration, N.Y. Times, Jan. 20, 2016, at A1.

31. Mistretta v. United States, 488 U.S. 361, 372 (1989).

32. Peter H. Aranson et al., A Theory of Legislative Delegation, 68 CORNELL L. REV. 1, 56-59 (1982); Morris P. Fiorina, Legislative Choice of Regulatory Forms: Legal Process or Administrative Process?, 39 PuB. ChOICE 33, 46-47 (1982). Presidents have augmented the congressional transfer of power with their own appropriation of policy making power. 
a broad range of voters, contemporary presidents generally hew to the partisan views that are representative of their political base..$^{33}$ Thus, while all citizens want to have a voice in their government, only half the public enjoys meaningful input into the development of presidential policy. It is no wonder that the party out of power spends more of its time trying to regain the Oval Office and less of its time trying to address the country's needs.

Under the current system, Democrats and Republicans fight tooth and nail to capture the White House. They spend hundreds of millions, now billions, of dollars. ${ }^{34}$ Moreover, once an election is over, each party launches its effort to win the next presidential race. The party of the President lines up behind the President's initiatives to ensure a successful administration. The losing party tries to block the President's proposals so it can persuade voters to change parties at the next presidential election. Thus, in 2009, former Senator Jim DeMint urged his colleagues to oppose the Affordable Care Act so they could "break" the Obama administration. ${ }^{35}$ Similarly, when George W. Bush proposed Social Security reform during his second term, congressional Democrats made opposition - rather than negotiation - their highest priority. ${ }^{36}$

To put it another way, strong partisan conflict can be expected under a winner-take-all system for a presidency whose power has grown to the level of the twenty-first century presidency. Currently, a candidate can win election with a small majority or even a minority of the popular vote. ${ }^{37}$ As a result, substantial numbers of voters feel that their interests and concerns are not represented in a politically dominant White House. When voters are disempowered, they become disaffected and receptive to a policy of partisan obstruction.

This is not to say that the presidency is the sole or even the primary cause of political polarization. Nevertheless, it plays an important role in exacerbating partisan conflict. Moreover, if reform of the executive branch can provide incentives for partisan cooperation, then the incentives can respond to conflict that arises from other factors.

33. Wood, supra note 9 , at 199-203.

34. Presidential Campaign, National Party, and Joint Committee Fundraising Through December 31, 2012, CAMPAIGN FIN. INST., http://www.cfinst.org/pdf/federal/president/2012/ Presidential\%20Fundraising\%20byCommittee_2012.pdf [https://perma.cc/W5YB-89RZ] (last visited Nov. 7, 2016).

35. Daniel Carty, GOP Senator Won't Retreat from “Waterloo" Comment, CBS NEWs (July 22, 2009, 8:19 AM), http://www.cbsnews.com/news/gop-senator-wont-retreat-from-waterloocomment/ [https://perma.cc/5XU8-UKT2].

36. Ronald Brownstein, The Second Civil War: How Extreme Partisanship Has Paralyzed Washington And Polarized AMERica 343-47 (2007).

37. SeeHistorical Presidential Elections, 270 To WIN, http:/www.270towin.com/historicalpresidential-elections/ [https://perma.cc/S3PW-MM74] (last visited Nov. 7, 2016). 


\section{The Single PRESIDENT AND DECISION MAKING IN THE EXECUTIVE BRANCH}

A one-person, very powerful presidency also invites decision making harmful to the country. The substantial increase in presidential policy making has changed the nature of presidential power. As indicated above, the Constitution envisions a President with secondary responsibility for the creation of national policy and primary responsibility for the execution of national policy. ${ }^{38}$

However, the contemporary President enjoys primary responsibility for both the creation and execution of policy. ${ }^{39}$ This assumption of policy-creating responsibility by the President allows national policy to be made in the absence of a robust debate among multiple decision makers who bring different perspectives to their decision making. It makes sense to have a single person who can act decisively and with dispatch when the person is an executor of policy made by others. But the founding fathers correctly reserved policy making for multiple-person bodies such as Congress and the Supreme Court. ${ }^{40}$ As Woodrow Wilson wrote, "The whole purpose of democracy is that we may hold counsel with one another, so as not to depend upon the understanding of one [person]."

Indeed, when it comes to making policy, there is much truth to the maxim that two heads are better than one. Studies by economists, psychologists, and other researchers demonstrate that shared decision making in small groups works better than unilateral decision making ${ }^{42}$ especially when the decision makers bring different perspectives to the table. ${ }^{43}$ As the example of George W. Bush waging war against Iraq illustrates, a single decision maker can make very poor choices. ${ }^{44}$

With the election of Donald Trump, the risks of misguided presidential policy making have become especially apparent. Trump's extreme policy proposals have unnerved many foreign governments, domestic military experts, economists, and

38. See supra note 15 and accompanying text.

39. See supra notes 24-30 and accompanying text.

40. U.S. CONST. arts. I-III.

41. Woodrow Wilson, The New Freedom: A Call for the Emancipation of the Generous Energies of A PeOple 72 (1961).

42. Alan S. Blinder, The Quiet Revolution: Central Banking Goes Modern 48-49 (2004); Susan G. Straus et al., The Group Matters: A Review of the Effects of Group Dynamics on Process and Outcomes in Analytic Terms vii, 2 (RAND Nat'l Sec. Res. Div., Working Paper No. WR-580-USG, 2009), http://www.rand.org/pubs/working_papers/WR580 [https://perma.cc/D7637S34].

43. See generally Charlan J. Nemeth et al., The Liberating Role of Conflict in Group Creativity: A Study in Two Countries, 34 Eur. J. Soc. Psychol. 365 (2004); Charlan J. Nemeth \& Margaret Ormiston, Creative Idea Generation: Harmony Versus Stimulation, 37 Eur. J. Soc. PsYchOL. 524, 526 (2007).

44. In large groups, as the workings of Congress illustrate, shared decision making can become worse than single decision making. But small groups are better than either individuals or large groups when the decision makers have different perspectives. 
American citizens. ${ }^{45}$ Critics of Trump would be much more comfortable if he had to secure the support of Hillary Clinton for his policy initiatives. ${ }^{46} \mathrm{~W}$ ith Clinton by his side, he would not be able to prohibit Muslims from entering the country, ${ }^{47}$ authorize torture of suspected terrorists, ${ }^{48}$ or promote policies that favor his and his family's business interests at the expense of the overall good. ${ }^{49}$

Of course, even single presidents do not make decisions in isolation. They consult with members of their cabinet and staff, so they enjoy many of the benefits of group decision making. Nevertheless, there is a big difference between deciding alone after consulting with advisers who are disposed to reinforce one's inclinations and sharing decision making with people who are disposed to challenge one's inclinations. Consider in this regard the difference between a Supreme Court of nine justices and a Supreme Court of one justice and eight excellent law clerks.

\section{Sharing Decision Making ACRoss Party Lines}

\section{A. Lessons from Abroad}

If concentrating power in a single person from one political party promotes dysfunction, it makes sense to consider reforms that would ensure a greater sharing of power among officials from different political parties. And in fact, many other political systems avoid the winner-take-all feature of the U.S. presidency through different power sharing arrangements. In European countries, coalition governments are common, and grand coalitions that span the political spectrum often result from parliamentary elections. ${ }^{50}$ For example, Austria has

45. James Kanter, European Leaders, Reeling, Meet to Weigh Fallout of U.S. Election, N.Y. Times, Nov. 14, 2016, at A9; Benjamin Din \& Andrew Merica, Retired Top Officers Back Clinton's Experience, Slam Trump, MiL. TIMES (Sept. 21, 2016), http://www.militarytimes. com/articles/retired-generals-release-video-supporting-clinton-for-president [https://perma.cc/HRE3-RH6K]; Nick Timiraos, Prominent Economists, Including Eight Nobel Laureates: 'Do Not Vote for Donald Trump,' Wall ST. J. (Nov. 1, 2016), http://blogs.wsj.com/ economics/2016/11/01/prominent-economists-including-eight-nobel-laureates-do-not-vote-fordonald-trump/ [https://perma.cc/2JQC-PTEH]; Julie Beck, How to Cope with Post-Election Stress, ATLANTiC (Nov. 10, 2016), http://www.theatlantic.com/health/archive/2016/11/how-to-cope-withpost-election-stress/507296/ [https://perma.cc/78UA-N7FH].

46. And critics of Clinton would be much more comfortable with her as a president if she had to secure the support of Trump for her policy initiatives.

47. Julia Preston et al., Trump Win Has Blacks, Hispanics and Muslims Bracing for a Long 4 Years, N.Y. Times, Nov. 10, 2016, at P8.

48. Charlie Savage, Obama Policies Give Successor a Path to Vast Security Powers, N.Y. Times, Nov. 14, 2016, at A1.

49. Danny Hakim \& Eric Lipton, With a Meeting, Trump Renewed a British Wind Farm Fight, N.Y. Times, Nov. 22, 2016, at A19.

50. See generally Hanna Bäck et al., Intra-Party Diversity and Ministerial Selection in Coalition Governments, 166 PuB. CHOICE 355 (2016). 
had grand coalitions more than half of the time since $1945 .^{51}$

Switzerland may provide the best model for institutionalized, broad power sharing. In Switzerland, the executive branch-the Federal Council-comprises seven department heads who possess equal decision-making authority. ${ }^{52}$ Decisions are made by consensus, with resort to a majority vote only in exceptional cases. ${ }^{53}$ For more than fifty years, the seven councilors have come from the major political parties (currently four) that represent roughly seventyfive percent of the country's voters ${ }^{54}$ and the councilors work cooperatively. ${ }^{55}$

With its broad sharing of power, the Swiss government has been able to avoid the kind of political conflict that the United States experiences-and that Switzerland once experienced-even though its population is socially more diverse than that in the United States. ${ }^{56}$ Switzerland has effectively melded its French, German, Italian, and Romansh citizens, as well as its Catholic and Protestant communities. ${ }^{57}$

Switzerland also had a nineteenth century civil war-less bloody than the U.S. Civil War and between Catholics and Protestants ${ }^{58}$ - and the Swiss drew an important lesson from their war. They concluded that to bridge social divides, it is important to ensure that all citizens have a voice in their government. ${ }^{59}$ It may well be the case that their politics of inclusion did much to defuse their social divisions. As former President Bill Clinton has observed, a politics of inclusion is the only politics "that works." ${ }^{60}$ Indeed, said Clinton, "It's the only thing that's working in American communities today."

51. Id. at 363 .

52. Wolf Linder, Swiss Democracy: Possible Solutions to Conflict in Multicultural Societies 4 (3d ed. 2010).

53. Id.

54. In the 2015 national elections, the four major parties won 76.2 percent of the vote. Strength of the Parties in the National Council, ElECTIONS 2015 (Oct. 2015), https://www.ch.ch/ en/elections2015/parteienstarke-im-nationalrat/ [https://perma.cc/F84V-RMBL]; see also Nationalratswahlen: Übersicht Schweiz, STATISTIK SCHWEIZ, http://www.politik-stat.ch/ nrw2015CH_de.html [https://perma.cc/SPJ6-PMYU] (last visited Nov. 23, 2016).

55. Ulrich Klöti, The Government, in HANDBOOK OF SwISs Politics 145, 155 (Ulrich Klöti et al. eds., 2nd ed. 2007).

56. Arend Lijphart, Patterns of Democracy: Government Forms and Performance In THIRTY-Six COUNTRIES 52-58 (2d ed. 2012).

57. LINDER, supra note 52, at 21-28.

58. Id. at 7.

59. Id. at 24-25.

60. Scott Pelley, Bill Clinton Talks About His Friendship with Nelson Mandela, CBS NEwS (Dec. 5, 2013, 7:38 PM), http://www.cbsnews.com/news/bill-clinton-talks-about-his-friendshipwith-nelson-mandela/ [https://perma.cc/9AZJ-536F].

61. Id. 


\section{B. The Benefits of Sharing Power Across Party Lines}

As the Swiss experience suggests, power sharing across party lines provides important benefits. ${ }^{62}$ First, it addresses the representation problem of winner-takeall elections. Instead of only half the public having meaningful input into presidential policy, power sharing in the Oval Office would ensure that almost all of the public has meaningful input. As David Fontana has written, shared power supplies "a more robust version of representation in politics, and hence a more robust version of legitimacy for democratic institutions." ${ }^{, 63}$

Shared power also can ensure that policy emerges from the reconciliation of a greater diversity of perspectives. Democrats promote principles of governmental regulation, Republicans promote free-market principles, and the two together can reach a balance between different perspectives that often eludes presidents from one party. Or to put it another way, the executive branch is more likely to identify policies that grow the economy or improve education when it works from a broader range of perspectives.

Presidential partners could provide more effective leadership than a single President not only when there is time for careful study and deliberation but also in times of crisis. Small group decision making can accommodate the need for rapid decision making. Presidents always confer with trusted advisers before making even the most urgent decisions. Consider in this regard the example of Israel, a country that has had to respond quickly to national security threats, and that has done so even though it convenes its security cabinet and then its full cabinet in response to a crisis. ${ }^{64}$

Moreover, some deliberation can be important in the face of unexpected events. In the summer of 2008, when Georgia and Russia waged their small war, many observers were quick to condemn Russia for its apparent aggression. ${ }^{65}$ As more information became available, it turned out that Georgia and Russia were both at fault. ${ }^{66}$

Why wouldn't shared power invite even greater gridlock? It could, but designed properly, there are good reasons to believe that power sharing would alleviate gridlock. If a minority party is given governing powers, then it assumes responsibility for the success or failure of governmental policy. Hence, it would have greater incentives for cooperation and weaker incentives for obstruction than currently. ${ }^{67}$

62. See supra Part IV.A.

63. David Fontana, Government in Opposition, 119 YALE L.J. 548, 590 (2009).

64. Nathaniel Kern \& Matthew M. Reed, Netanyahu's Divided Cabinet, MidDLE E. PoL'Y Council Foreign ReP. Bull. (Aug. 28, 2006, 11:34 PM), http://www.mepc.org/articlescommentary/commentary/netanyahus-divided-cabinet?print [https://perma.cc/BKM7-A2KM].

65. Georgia Crisis Tests Presidential Candidates, CNN (Aug. 11, 2008, 8:40 PM), http://www.cnn.com/2008/POLITICS/08/11/candidates.georgia/ [https://perma.cc/H2NR-W933].

66. Ellen Barry, War Report Said to Fault Both Russia and Georgia, N.Y. Times, Sept. 29, 2009 , at A4.

67. Fontana, supra note 63, at 597-98. 
Indeed, at the presidential level, that especially would be the case. With its current winner-take-all, high stakes elections, the presidency is designed to maximize incentives for obstruction. The losing party greatly increases its chances to win the next presidential election by undermining the current President. If executive power were shared, then the payoff from obstruction would diminish, and the payoff from cooperation would increase.

More specifically, the incentives for obstruction could be greatly reduced and the incentives for cooperation greatly enhanced if the United States adopted something like the Swiss model for the executive branch. Recall that the executive power in Switzerland is shared by the four major parties and that the executive councilors operate by consensus ${ }^{68}$ Because there are only two major parties in the United States, the analogous arrangement would be a co-presidency, with representation from the Democratic and Republican Parties. ${ }^{69}$ And the two presidents would operate on the basis of consensus - the approval of both would be required to sign a bill into law, to issue an executive order, or to nominate a Supreme Court justice.

Instead of having the top vote-getter assume the presidency, the top two votegetters from different parties would become presidential partners. The different parties would still nominate their presidential and vice-presidential candidates as they do now, and voters would still have one vote in November, but two presidents from different parties would be inaugurated in January. Ordinarily, the co-presidents would be a Democrat and Republican, but there may be times when a strong third-party or independent candidate would run second and share the Oval Office with either a Democrat or Republican. ${ }^{70}$

In a bipartisan executive, the presidential partners would have little incentive to develop a relationship of conflict. Elected officials are highly partisan, but they are partisan for a purpose. Typically in U.S. politics, one person can hope to establish a dominant position by outmaneuvering the other person. If the United States required an equal sharing of power in the Oval Office, partisan maneuvering could not lead to an enhancement of power.

Not only would presidential partners lack an incentive to engage in conflict; they also would have an important incentive to work cooperatively. Having

68. See supra Part IV.A.

69. Two presidents would be sufficient to give broad representation to the public, so I start with that alternative. But other redesigns of the executive branch also should be considered. See infra Part VI.

70. The possibility of a successful third-party candidate would be much greater. Currently, supporters of a third-party candidate worry that voting for their first choice might doom their second choice. Indeed, many people think that Ralph Nader's candidacy gave the presidency to George W. Bush in 2000 by drawing votes from Al Gore. See, e.g., Alan Abramowitz, The Time for Change Model and the 2000 Election, 29 AM. PoL. RES. 279, 281 (2001) (observing that if Nader had not been on the ballot, "it seems almost certain that Mr. Gore would have carried both Florida and New Hampshire and thereby had a clear majority in the electoral college"). With a bipartisan executive, it would have been safe to vote for Nader knowing that a second-place finish for Gore would have been as good as a first-place finish. 
reached the pinnacle of political life, presidents care most about their legacies. ${ }^{71}$ George W. Bush's decision in 2003 to invade Iraq and overthrow Saddam Hussein is illustrative. While there were a number of reasons for his decision, it appears that he was influenced by the potential for introducing democratic governance to the Arab Middle East and providing a model that could spread to neighboring countries. ${ }^{72}$ The possibility of transforming a major region of the world overcame his opposition during the presidential campaign to policies of "nation-building." ${ }^{, 73}$ Similarly when Barack Obama was deciding in 2009 whether to pursue health care reform, he rejected the advice of his political advisors to remain focused on the economy because he believed that for greatness as a President, he needed to pass health care reform. ${ }^{74}$

If the members of a coalition presidency spent their terms locking horns, they would not be able to implement key proposals that could enhance their reputations and burnish their legacies. Accordingly, they likely would come to accommodations that would allow them to implement meaningful policy changes and generate an impressive record of accomplishment. In other words, presidential partners would tend toward cooperation not out of devotion to the public good but out of self-interest.

That people with strong philosophical differences would work cooperatively may seem surprising. But public officials typically exhibit flexibility in their positions in order to achieve their political goals. As governor of Massachusetts, Mitt Romney championed the kind of health care reform that he later opposed as a presidential candidate. ${ }^{75}$ U.S. Senator Arlen Specter moved to the left after switching from the Republican Party to the Democratic Party, ${ }^{76}$ and former U.S. Senator Evan Bayh had a much more liberal voting record when he was contemplating a presidential bid and trying to appeal to Democratic primary voters throughout the country than when he was contemplating a re-election bid and trying to appeal to Indiana general election voters. ${ }^{77}$

While there is ample reason to think that a bipartisan executive would function effectively, inefficiency is not a ground for denying citizens a voice in

71. See, e.g., Emily J. Charnock et al., What to Expect in the Second Term: Presidential Travel and the Rise of Legacy Building, 1957-2009, IsSUES IN GOVERNANCE StUdies No. 54 (The Brookings Inst., Washington, D.C.), Dec. 2012, at 1-8.

72. Victor Davis Hanson, Why Did We Invade Iraq?, NAT'L REV. (Mar. 26, 2013, 4:00 AM), http://www.nationalreview.com/article/343870/why-did-we-invade-iraq-victor-davis-hanson [https://perma.cc/YYK8-Y5KZ].

73. Id.

74. Jonathan Alter, The Promise: President Obama, Year One 244-46 (2010).

75. Kitty Bennett et al., Comparing Two Health Care Laws, N.Y. Times (Nov. 14, 2011), http://www.nytimes.com/interactive/2011/11/15/us/politics/comparing-two-health-care-laws.html [https://perma.cc/ZS7F-ESSJ].

76. Katharine Q. Seelye, Senator Specter Becomes Focus of Anti-Incumbent Fervor, N.Y. Times, Jan. 27, 2010, at A12.

77. Ezra Klein, The Strange Case of Evan Bayh, Am. РRоSPeCt (Apr. 3, 2009), http://dev01. prospect.org/article/strange-case-evan-bayh [https://perma.cc/TSY9-JM4A]. 
their government. Democracy rarely makes for efficient governance. Nevertheless, we do not allow presidents the powers of a dictator. Representation should not be sacrificed for efficiency. Rather, efficiency can be pursued once representation is guaranteed. In the case of the executive branch, full representation does not exist as long as we have a single President from one party.

\section{Concerns About a Bipartisan Executive Are Misplaced}

Some people may object to a bipartisan presidency on the ground that the candidate with the most number of votes would share power equally with a candidate with fewer votes. Even though Barack Obama topped Mitt Romney by a margin of fifty-one percent to forty-seven percent in the popular vote, ${ }^{78}$ they each would have had fifty percent of the power in a bipartisan presidency.

It may seem unfair to give Obama only fifty percent of the power when he earned a majority of the vote. But that unfairness pales in comparison to the unfairness of Obama possessing 100 percent of the power after securing only fifty-one percent of the vote. Indeed, winner-take-all systems generate the highest levels of electoral unfairness among governmental systems. ${ }^{79}$

The unfairness of a one-person presidency is exacerbated by the fact that the United States holds one vote on one day that decides control for thousands of decisions that will be made over a 1,461-day stretch. The majority wins not only on Election Day but on every day thereafter for four years. Majority rule can quickly become rule that ignores the interests of half the public for long stretches of time.

To be sure, on a decision-by-decision basis, the majority ordinarily should prevail. When a choice must be made, the majority's preferences rightly take priority over the minority's preferences. However, over a series of many decisions, majority rule can be unjust. We generally trust majority rule because the composition of the majority will vary from one decision to another. The losers on some votes will be winners on other votes. Majority rule becomes unfair when some people are persistently in the minority, so they always lose out. As U.S. Supreme Court Justice Byron White wrote, the Constitution is violated when "a particular group has been ... denied its chance to effectively influence the political process." ${ }^{\prime \prime 0}$ And with a one-person, one-party presidency, members of the other party are effectively denied their ability to influence executive branch policies for four years.

78. Popular Votes 1940 - 2012, Roper CTR. FOR Pub. OpInION Res., http://ropercenter. cornell.edu/polls/us-elections/popular-vote/ [https://perma.cc/Y4QQ-SRTY] (last visited Nov. 7, 2016).

79. See generally Arend Lijphart, Presidentialism and Majoritarian Democracy: Theoretical Observations, in The Failure of Presidential Democracy 98 (Juan J. Linz \& Arturo Valanzuela eds., 1994). Proportional representation systems do a much better job than winner-takeall systems at promoting fairness. See generally $i d$. With proportional representation, legislative seats are apportioned in proportion to a party's vote.

80. Davis v. Bandemer, 478 U.S. 109, 132-33 (1986). 
Why wouldn't partisan conflict in Congress undermine any benefits from conciliation in the Oval Office? Even if co-presidents would cooperate, how would they overcome partisan conflict on Capitol Hill? During the Obama presidency, Republican senators and representatives exploited the disaffection of Republican voters by a policy of obstruction. ${ }^{81}$ Similarly, during the George W. Bush administration, Democratic senators and representatives exploited the disaffection of Democratic voters by a policy of obstruction. ${ }^{82}$ But with a bipartisan executive, neither party's voters will be disaffected and receptive to a policy of obstruction. Many of Senator Ted Cruz's constituents applauded his efforts to frustrate President Obama. They would not have been as happy if he were trying to frustrate an Obama-Romney presidency.

It is not only the case that incentives to fight the White House would dissipate. The party out of power also would have incentives to cooperate. For example, the party's members of Congress could share credit for presidential achievements. If Republicans had voted for the economic stimulus in 2009 or health care reform in 2010, they would not have gotten much credit for their votes. Both statutes were seen as Democratic initiatives. ${ }^{83}$ Hence, Republicans could earn political credit only by voting against the bills and hoping they went down to defeat or were unsuccessful. In contrast, both parties could receive credit for legislative initiatives that emerged from a bipartisan executive.

There is a second important way in which a bipartisan executive would increase incentives for cooperation between the White House and Capitol Hill. Members of Congress on both sides of the aisle would have greater opportunities to help their constituents by cultivating warm relationships with the executive branch. As I found during my service in the Indiana House of Representatives, legislators often do more for their districts by cutting through governmental red tape than by passing bills. But I also found that I could help my constituents with the executive branch only when it was headed by a governor of my own party. Similarly, presidents favor the districts of their party colleagues in Congress. ${ }^{84}$

81. See, e.g., Carl Hulse \& Adam Nagourney, Senate G.O.P. Leader Finds Weapon in Unity, N.Y. Times (Mar. 16, 2010), http://www.nytimes.com/2010/03/17/us/politics/17mcconnell.html? pagewanted=all\&_r $=0$ [https://perma.cc/ZMH3-YETA]

82. See, e.g., Charlie Spiering, After Bush Was Re-Elected in 2004, Democrats in Congress Did Not Compromise, WASH. EXAMINER (Nov. 7, 2012, 12:00 AM), http://www. washingtonexaminer.com/after-bush-was-re-elected-in-2004-democrats-in-congress-did-notcompromise/article/2512871 [https://perma.cc/VNA3-DVJJ].

83. See Lee Hudson Teslik, The U.S. Economic Stimulus Plan, Council on ForeIGn Rel. (Feb. 18, 2009), http://www.cfr.org/united-states/us-economic-stimulus-plan/p18348 [https://perma.cc/EJ2R-2LGQ]; Shailagh Murray \& Lori Montgomery, WASH. Post (Mar. 22, 2010), House Passes Health-Care Reform Bill Without Republican Votes, http://www. washingtonpost.com/wp-dyn/content/article/2010/03/21/AR2010032100943.html [https://perma.cc/Y5GR-JZQB].

84. Matthew Soberg Shugart \& John M. Carey, Presidents and Assemblies: Constitutional Design and Electoral Dynamics 31 (1992); see also Christopher R. Berry et al., The President and the Distribution of Federal Spending, 104 AM. Pol. SCI. REV. 783 (2010) 
Hence, Republicans had less to gain than Democrats during the Obama administration through their relationships with the executive branch. In a bipartisan executive, members of Congress from both parties could gain much by cooperating with the White House.

Would a bipartisan executive result in too much compromise and not enough vision? Recall from the studies on decision making that shared decision making works better than individual decision making. ${ }^{85}$ Overall, we would get better decisions from a bipartisan executive than from a single executive. Moreover, even if exceptional leaders exist who would make better decisions than a bipartisan executive, voters often will choose alternative candidates. For every Franklin Delano Roosevelt who ascends to the presidency, a Herbert Hoover, Warren Harding, and Calvin Coolidge also ascend. And even visionary leaders are a mixed bag. Lyndon Johnson championed the Great Society, but he also escalated the Vietnam War. ${ }^{86}$

In addition, as the founding fathers recognized, the benefits of avoiding bad decisions outweigh the losses from missing out on good decisions. When Alexander Hamilton justified the presidential veto in Federalist Paper No. 73, he argued that the veto's restraint on the legislature would be "much more likely to do good than harm. ${ }^{" 87}$ As Hamilton wrote, the disadvantage from defeating good laws "will be amply compensated by the advantage" of preventing bad laws. ${ }^{88}$ For many voters, the election of Donald Trump as President highlights the importance of protecting against bad laws.

Of course, the kinds of arguments against a two-person executive also were made in opposition to equal rights for women. A household needed a single, decisive leader, and shared authority would fail. But we have come to recognize that when there are major decisions to be made for a family, wives should share decision-making authority with their husbands.

To be sure, marriages often result in divorce. But the point about the marriage analogy is not to argue that presidential partners can or should have a marital-like relationship. Rather the point is that decision making is improved by including more stakeholders in the decision-making process. Marriages may not work as well as we would like, but they would work far less well if we assigned decisionmaking authority to only one person in the relationship.

(finding that presidents direct more federal spending to congressional districts held by members of their own party); Sanford C. Gordon, Politicizing Agency Spending Authority: Lessons from a BushEra Scandal, 105 AM. PoL. SCI. REV. 717 (2011) (discussing efforts by the administration of George W. Bush to direct federal spending to priority congressional districts for the Republican Party).

85. See supra Part III.

86. Frances M. Bator, No Good Choices: LBJ and the Vietnam/Great Society Connection, 32 Diplomatic Hist. 309, 309 (2008).

87. See generally The Federalist No. 73 (Alexander Hamilton) (Lawrence Goldman ed., 2008).

88. Id. 


\section{Sharing Legislative Power Across Partisan Lines}

If presidential power should be shared, should legislative power also be shared? Should each congressional district be represented by two officeholders? I have focused on executive power because of its winner-take-all, high stakes nature. The power of Congress already is divided, both between a House and Senate, and between the two parties. If Republicans enjoy a majority in one chamber and Democrats in the other, the parties are forced to share power. Moreover, the filibuster rule gives the minority party in the Senate leverage with which to exert influence ${ }^{89}$ However, the minority party can lose its voice in the House, where a simple majority is enough to exercise control. Hence, it would be useful to give the minority party greater power by adopting a filibuster rule in the House.

\section{Promoting Diversity in the Executive Branch Along Other Lines}

In addition to promoting partisan diversity in the executive branch, would it also be valuable to promote diversity along ethnic, gender, or racial lines? In Switzerland, two of the seven seats in the executive cabinet are reserved for representatives of the minority French and Italian communities..$^{90}$ In a bipartisan executive, multiple kinds of diversity also could be fostered. For example, it might be possible to have a male and female co-president from each party, who run as a ticket, giving us four presidents.

On one hand, concerns about representation and voice are important for all persons, and even two presidents may come from only one sex and one racial background. A wise Latina woman can bring an important perspective that eludes many white men. ${ }^{91}$ On the other hand, the empirical evidence suggests that a person's political affiliation may be much more important than other group identifications for political representation. For example, women voters care much more about the political party than about the sex of candidates for political office. $^{92}$ Thus, female Democrats are much more likely to vote for male Democrats than for female Republicans, and female Republicans are much more likely to vote for Republican men than for female Democrats. ${ }^{93}$

89. See Fontana, supra note 63 , at 557.

90. Marcus Crepaz \& Jurg Steiner, European Democracies 92 (8th ed. 2013).

91. Sonia Sotomayor, Supreme Court Justice, Keynote Address at Judge Mario G. Olmos Memorial Lecture at the UC Berkeley School of Law Symposium: Raising the Bar: Latino and Latina Presence in the Judiciary and the Struggle for Representation (Oct. 26, 2001) ("I would hope that a wise Latina woman with the richness of her experiences would more often than not reach a better conclusion than a white male who hasn't lived that life."), http://www.berkeley.edu/ news/media/releases/2009/05/26_sotomayor.shtml [https://perma.cc/D75G-W9WS].

92. Kathleen Dolan, Gender Stereotypes, Candidate Evaluations, and Voting for Women Candidates: What Really Matters?, 67 PoL. RES. Q. 96, 98, 104 (2016).

93. Id. According to exit polling, a majority of white women voted for Donald Trump over Hillary Clinton for President in 2016. Sheryl Gay Stolberg, The Women Who Helped Trump to Victory, N.Y. Times, Nov. 11, 2016, at A1. 
Perhaps it would make sense to add partisan diversity to the executive branch as a first step and then consider whether further changes in the executive branch would be desirable to promote other kinds of diversity.

\section{CONCLUSION}

Concerns about partisan conflict and the interest in effective decision making both point to the need for a sharing of executive power across partisan lines. As the presidency has assumed more and more policy-making power, it becomes untenable to rest the executive power in the hands of a single person from one side of the political aisle, especially when that person exhibits strongly authoritarian tendencies. A bipartisan executive would do much to correct the dysfunction of the U.S. political system. 